\author{
Józef Dąbrowski \\ mgr inż. \\ Zakład Trakcji Elektrycznej \\ Instytut Elektrotechniki, Warszawa \\ j.dabrowski@iel.waw.pl
}

DOI: 10.35117/A_ENG_17_06_05

\title{
Systems of protection against stray currents, their monitoring and protection against electric shock in the second metro line in Warsaw
}

\begin{abstract}
The paper presents a system of passive protection against stray currents that was applied to the central section of the second metro line in Warsaw. Stray currents monitoring system deployed on this stretch of metro line was described. The assessment of the criteria for abnormal states and electrochemical corrosion risks of the underground infrastructure were given. The author also presented the principles used in Stray Current Monitoring (SCM) for signalling short circuits between subway rails and subway construction. Passenger and staff safety system was described too.
\end{abstract}

Keywords: Systems of protection; Metro; Current straying

\section{Introduction}

On 8/03/2015, a central section of the second metro line in Warsaw was opened for passengers. At the INFRASZYN 2016 conference, the security systems working on this section of the underground were presented [17]. During the operation of the first metro line in Warsaw, significant changes could be observed regarding the safety of both passengers and the entire metro infrastructure. It was related to the events that took place in this world in various operating underground lines. The author of the paper [17] presented a number of issues related to the infrastructure and its safety as well as service and passengers in operation already introduced at the design stage. In his conference presentation, however, he did not mention a part of the systems related to both direct and indirect safety of passengers and metro servicing. Therefore, the following material complements it. Direct safety, especially of passengers getting on and off the metro cars, is related to the fact that the vehicle is located on the potential of rails on which the wagons move, and the passenger are on the platform's potential. These potentials are usually different and may be at a dangerous level for humans. Intermediary safety is related to the long-term impact of the variable potential of railways electrified by direct current of ground and underground transport. Regardless of the location of the rails, this phenomenon is related to stray currents and electrochemical corrosion of underground metal structures.

The underground electric traction supply system is a direct current system with a rated voltage of $750 \mathrm{~V}$. According to the recommendations of the Railway Institute, the power supply system is the same as on the first metro line. Thanks to this, on the section of about 6 $\mathrm{km}$ we have 4 traction substations supplying the trail as well as one with a supercapacitance tank and fields supplying holding tracks. Requirements of protection against electric shock for ac and dc traction systems are given in the standard [14], and in the case of direct current (dc) a number of recommendations from [14] is the opposite to the requirements for protection against stray currents [15] from the return network of the traction system dc environment. This issue is discussed in more detail in the literature [5]. 


\section{Construction of stations and tunnels on the second line from the point of view of protection}

The construction of tunnels on the second metro line consists of round reinforced concrete tubs with a length of over $1.1 \mathrm{~m}$. The tubing ring with a diameter of more than $5.5 \mathrm{~m}$ is made of seven reinforced concrete segments that fill the space behind the tunnel that penetrates it and separate the external electrolyte soil from the inside. Both the tubing segments and the rings themselves are sealed with a plastic spacer, which is installed in special grooves at the edges of the front segments and tubings. The outer layer of concrete over the segment reinforcement provides water and electrical insulation. From the inside, in each segment, brands with metallic contact with segment reinforcement are derived. The random impulse [9] and frequency [10] measurements showed that in the state after assembling the tunnel structure between segments in the ring as segments of neighbouring rings, the resistance ranges from several to several dozen $\Omega$. From the point of view of electrical insulation for 230 $\mathrm{V}$ in electrical outlets, this low resistance means that the reinforcement of individual tubing segments are isolated from each other and from the external electrolyte soil because the voltage differences between these segments will not reach such large values.

Nothing can be said about the insulation of structures made by the diaphragm wall technique, i.e. track fans, and station bodies on the II metro line. Metro stations with two or three passenger compartments, turnouts and storage tracks have not been equipped with electrically isolated dilatations, e.g. at the intersection of individual chambers. Thus, these constructions were deprived of the possibility of controlled passive protection of them against stray currents coming from foreign sources, e.g. tram and railway traction or soil macro-cells. At the same time, the lack of such dilatations makes impossible to conduct the measurement of the conductance of the body transition of the station already built in relation to the surrounding electrolyte soil. In this case, only experience in the construction and operation of the first line remains, where the station's bodies were also made using the diaphragm wall technique. On the first line, these structures are deprived of an insulating layer, as well as drilled tunnels made of iron tubings [8]. Therefore, we have the case predicted in [4] on the second line, where the bodies of structures made using diaphragm walls are earthing, and tunnel constructions correspond to cable connections between the earth electrodes. The above solution results from the fact that internal metal installations arranged in tunnels, in particular metal cable trays and earthing conductor passing through all structures, connect them also electrically. A similar function is fulfilled by screens of MV and LV power cables connected in places of connection to switchgears and receivers in order to ensure paralysis safety. Teletechnical cable screens are connected at the ends to the reinforcement in order to eliminate interference from the communication, electronic, power electronics and electrical devices operating within the metro structure. These connections also contribute, although to a much smaller extent, to equalizing the potentials between structures made of diaphragm walls. In addition, in the tunnels, the internal equipotentialisation of all tunnel segments located above the level of the track slab is made. The electrical shock protection from $50 \mathrm{~Hz}$ alternating current from the power system is provided by the system of foundation earth electrodes in station bodies and track ventilation rooms as well as a five-lead low voltage installation in the TN system.

\section{A protection system against stray currents}

Underground construction of the metro, and more precisely its reinforcement, is exposed to the impact of external sources of current flowing in the ground and its own traction system. In Warsaw conditions, external sources include railway and tram railroads, macroelasters occurring in the city [14], and telluric currents originating from disturbances of electromagnetic radiation of the sun. As established [12] irregularity of occurrence of 
magnetic storms phenomena and different direction of the flow of telluric currents do not cause corrosion damage in underground constructions, although they contribute to damage in electric power systems. Impacts of the railway and tram system depend on the rolling stock, timetable, condition of the return network and weather conditions, as well as to a large extent from the mutual location relative to the underground structure. One of the methods of passive protection against the effects of currents in the ground is the insulation of the structure from the soil electrolyte, the other is the change of the longitudinal resistance of the structure by inserting transverse insulation securing a long structure. In the pipelines, this insulation is constituted by monoblocks. The other protection methods belong to the active group and have been omitted in this work. On the second metro line, the construction of tunnels and its reinforcement is isolated from the external soil electrolyte, which means the use of a protection against the impact of stray currents on tunnels. In order to reduce the current exchange between the station structures and track ventilation rooms of the central section of the second line, the tunnels were isolated from the ground soil electrolyte to introduce sectioning of sections with diaphragm wall structures. Only thanks to this external insulation in the tunnels it was possible to obtain transverse dilatation with insulation by making breaks in the continuity of the grounding bus and in cable trays on selected tubular sections. Thanks to this, it was possible to separate the bodies of neighbouring stations and touring stations from each other. Before the effectiveness of this protection against currents was checked, single breaks were tested and the fire safety and selectivity of protection was checked against short circuits in low-voltage AC networks supplying objects such as traffic control or lighting installed in tunnels and track ventilation rooms. Positive results of short-circuit loop impedance measurements and resistance of earthing were obtained, both at compact and open junctions on expansion joints in tunnels, thanks to which a passive protection system against stray currents, especially from foreign sources, was allowed to be used. In order to minimize the impact of the own return network built inside the structure, care should be taken to isolate the rail network and the apparatus connected to it from the structure. The foundation and fastening of the track in the EBS system with correct performance and lack of dripping, and still more standing water on the substructure in which the rail foot would be submerged, promotes obtaining the unit conductance of the rail passage, a single-track tunnel required in the standard [15] issued in 1998. An essential disadvantage of the central section is the length of the track without the possibility of dividing it into shorter sections. This makes it difficult to determine the locations of short-circuits between the traction return network and the reinforcement of the underground structure in a significant way, which was already experienced during operation. The Stray Current Monitoring System provides an assessment of the effectiveness of the protection against currents wandering all sources on the subway construction.

\section{Stray Current Monitoring System}

In order to select the connection system of the passive protection system against stray currents on the central section of the second subway line, a measurement and recording system called the Stray Current Monitoring system (SCM) is performed, whose task is to record and store measured values, and signal the occurrence of short-circuits between the return network subway and construction. The SCM system is all-linear, but consists of individual measuring cabinets located in the station and ventilation room structures. Four alphanumeric characters provide a description of the cabinet, which uniquely determines the position of the point in the construction of the central section. Each cabinet covers the area in which the following quantities are measured:

$\mathrm{ST}$ - voltage between the structure and rails in the place where the cabinet is installed;

$\mathrm{S}$ - voltage drop in the rails between measuring cabinets V; 
TC - design potential relative to the zinc reference electrode protruding from the V structure; $\mathrm{T}$ - voltage drop on the structure in $\mathrm{mV}$ with the possibility of conversion into the value of current flowing in the construction A;

SKT - voltage between railway rails and the construction of the V metro;

STrT - voltage between the tram rails and the V metro structure;

IP - current of the traction substation supplying metro A vehicles.

Figure 1 shows the schematic diagram of the distribution of measurement cabinets in the construction of the central section of the second subway line and the size of TC and T. Measurement cabinets, as well as electrodes are installed at stations and trail ventilation rooms. In the case of three-chamber $\mathrm{C} 09$ and $\mathrm{C} 15$ stations, three cabinets were placed, while the other two and one in each ventilation room. At the odd stations there are traction substations supplying metro trains. From the collective shunt in the cabinet of return cables to the MPB system, signals are introduced proportional to the amount of current drawn from the substation.

In places of close-ups, intersections and the common route of tram and railway rails, the tensions between these rails and the structure are recorded. The description of each registered size allows you to intuitively identify the place from where it comes from.

Measuring cabinets contain analogue digits with analogue signal input ranges suited to the measured quantities. The number of transmitters in the cabinet depends on the number of signals measured. The order of occurrence of signals in cabinets is stored in the configuration file. Thanks to this, digitized signals are sent from the cabinets via fibre optic Ethernet to the server in the Central Control Room. From each cabinet on the central section of the second metro line, you can use the software loaded on the laptop to check if the others are currently working, preview what instantaneous values are recorded with a frequency of $2 \mathrm{~Hz}$ and lose the recorded data for the last month. Earlier data is available on the server in CD. The specialized ANPRB2 software is used to visualize the results of the MPB system. The visualization applies to all quantities recorded in the MPB, which can be assembled by measuring centres, i.e. groups of up to four measurement cabinets installed next to each other within an odd station, or selected one for the entire section or from several cabinets. Using the program allows you to get results for any period of time, if there are files available with registration and in this time interval there were no changes in the configuration, i.e. the work of all elements of the entire system. The presentation can be in a tabular form of "basic results" containing a combination of extreme values, positive and negative averages as well as a ratio of positive and negative signals in the analysed time interval. For example, in Table 1, a printout from the screen of the tabular summary of the ST voltage measurement results of the subway bus - reinforcement of the subway structure registered on November 23, 2015 from 7:00 to 8:30. The results can also be presented in the form of graphical charts of time courses of instantaneous and 30-minute averages, and for the time interval on the road scale, i.e. along the construction. Figures 2 and 3 show the results from Table 1 in the form of diagrams from instantaneous values and from averaged values, respectively. The software also enables correlation analyses, creation of histograms, which at the present stage are to serve cognitive and comparative purposes, e.g. with applied in practice risk assessment criteria. 


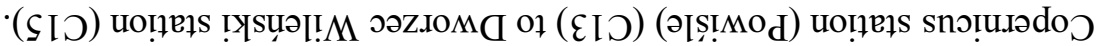

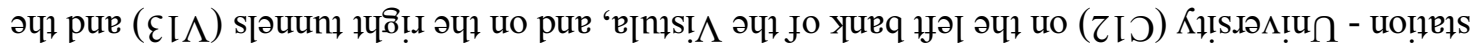

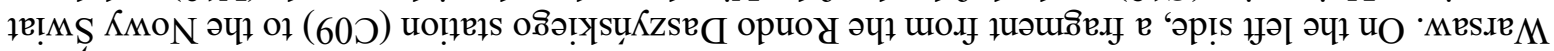

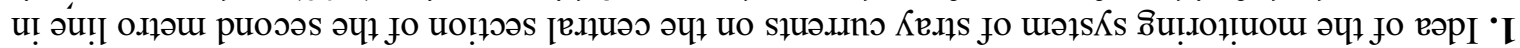

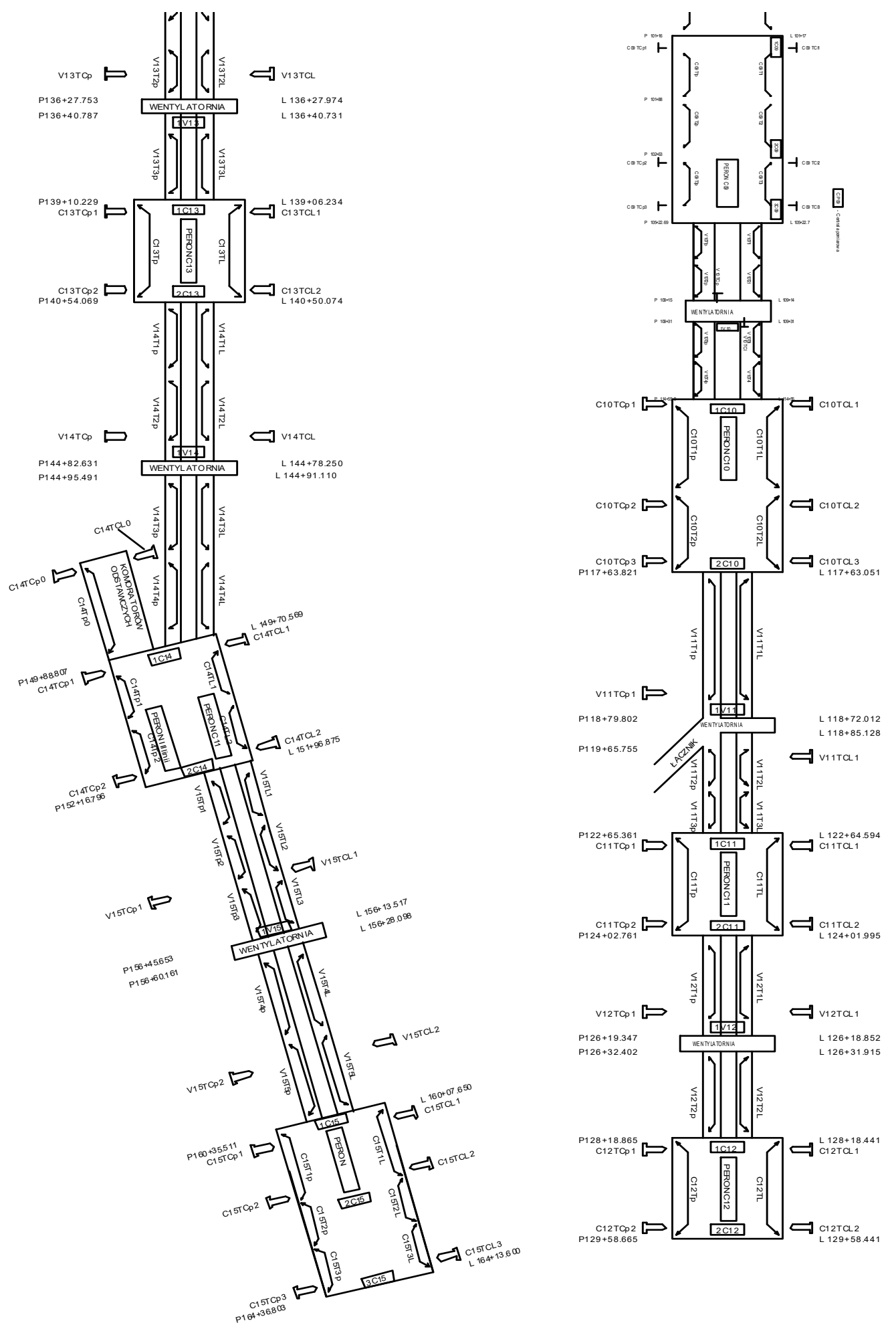




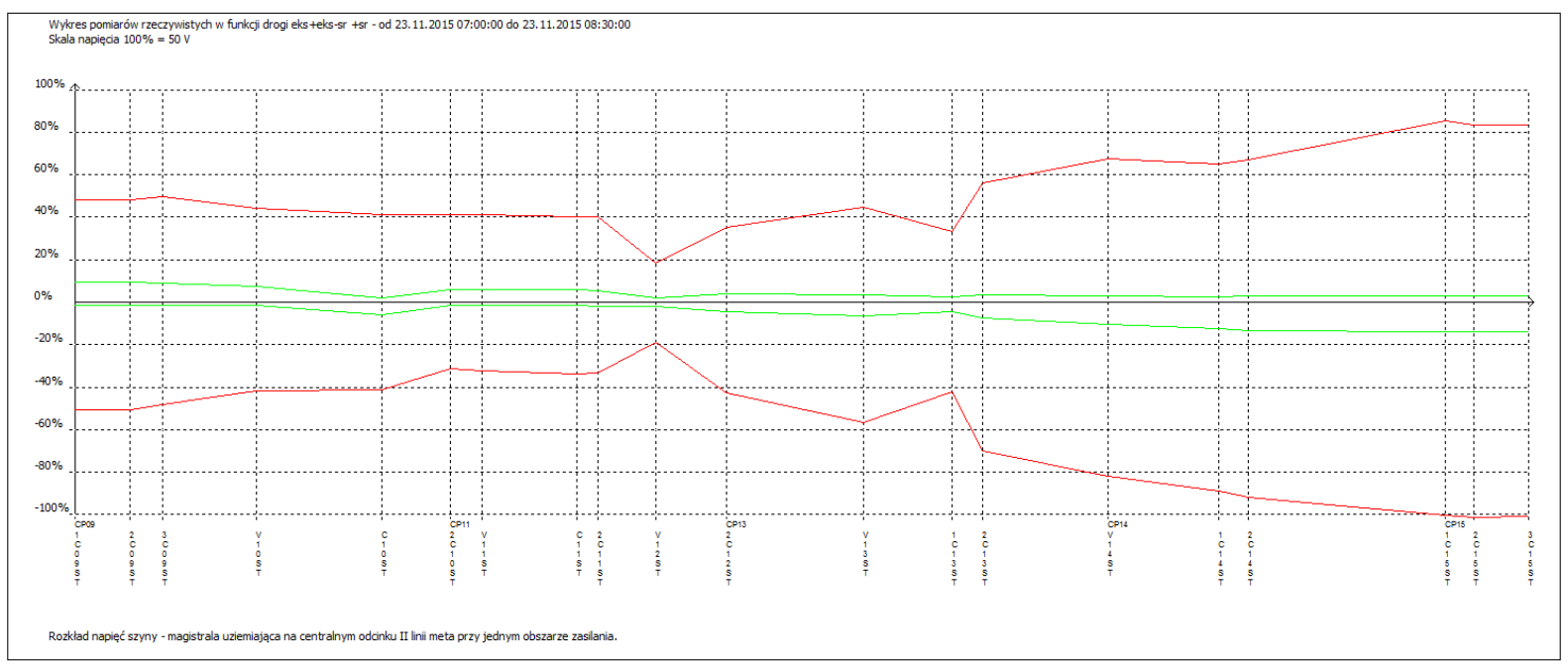

2. An example diagram of bus voltage distribution along the central section of the second metro line registered on November 23, 2015 between 7:00 and 8:30. The graph was created from instantaneous real values. The red colour indicates the extreme value occurring in the analysed time interval; green colour means positive and negative mean values for the same time interval. Table 1 shows the values of these voltages in tabular form.

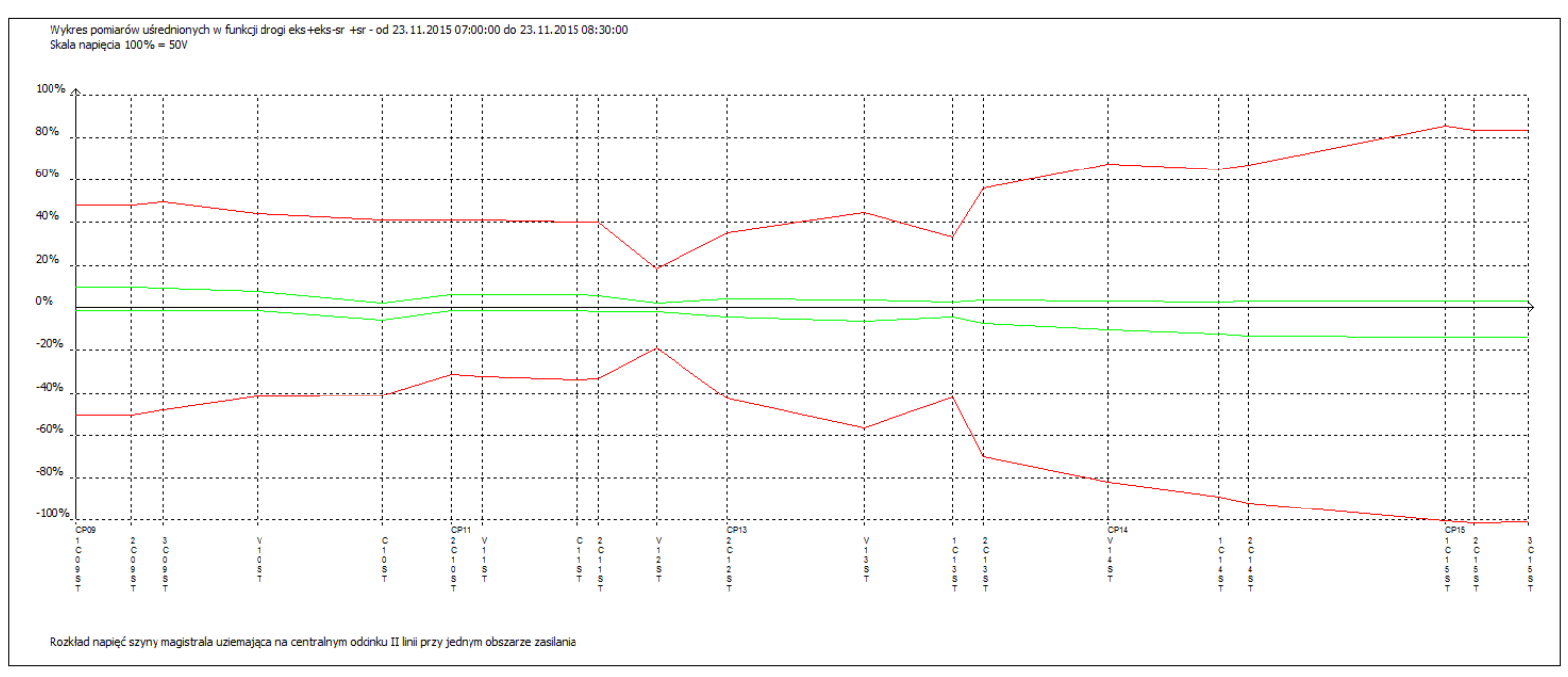

3. An example diagram of bus voltage distribution along the central section of the second metro line registered on November 23, 2015 between 7:00 and 8:30. The graph was formed from averaged values. The red colour indicates the extreme values occurring in the analysed time interval; green colour means positive and negative mean values for the same time interval. Table 1 shows the values of these voltages in tabular form.

Since the diagrams in Figures 2 and 3 relate to the same time interval included in full and half-hour time intervals, both graphs will be the same. The averaged values stored in the program are counted in 15 minutes. The 30-minute time interval used in the analysis of results is the result of experiments in the measurement of corrosion hazards from stray currents of various underground metal structures. 
Table 1. List of extreme values and average bus voltage ST tunnel along the central section of the second metro line registered on November 23, 2015 r. 7:00 to 8:30.

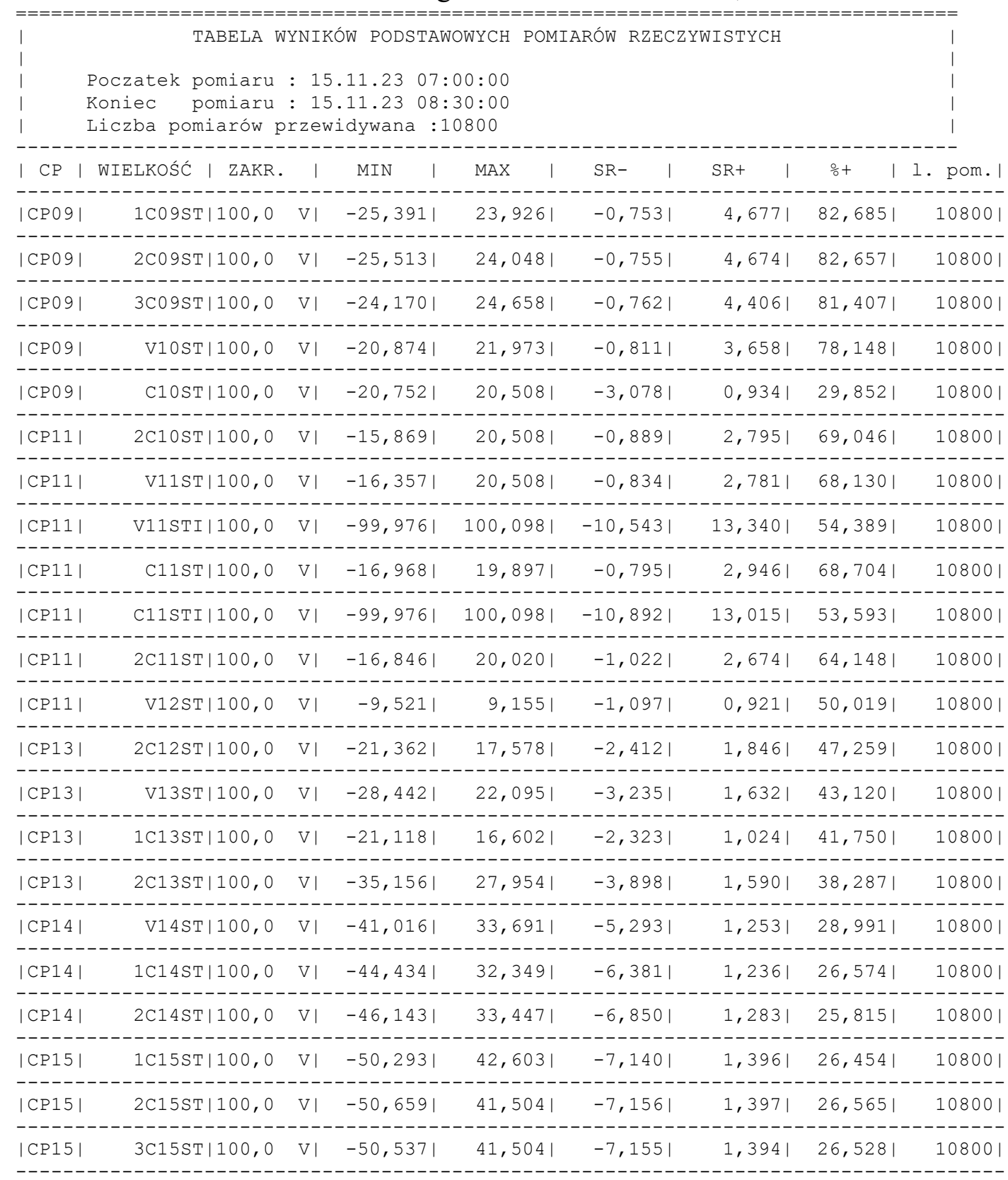

Note: The sizes of V11STI and C11STI are the bus voltage of the first metro line relative to the body's reinforcement, respectively, between the two lines and the C11 station. It should be noted that in this statement they are two values with the highest extreme and average values.

The first column of Table 1 defines the measuring centre i.e. the station with traction power around which the quantities are measured and archived. In the second column there is a description of the size, thanks to which it is known in which measuring cabinet it exists, and in the third column the measuring range of the transducer used is given. The next four columns are successively the extreme minimum and maximum values as well as the negative and positive mean values. The next column gives the percentage of the value above zero from the number of samples given in the last column. Most often, the number of samples corresponds to the declared time interval of the analysis performed at a sampling rate of $2 \mathrm{~Hz}$. 
In the case where the number is smaller, it means that the missing number of samples has been lost, e.g. when transmitting or converting an analogue signal into digital.

\section{Risk assessment from stray currents}

Initial assessment of the impact of individual traction sources on the subway construction is made by calculating the positive and negative mean values from the voltage between the structure and the rails: ST, SKT and STrT during one day. According to the literature [7], only exceeding the standard values [13] should be considered as a threat, while values below these thresholds require additional information. A more robust approach to source assessment is to calculate average values from rush hours, when traffic is the largest as well as the expected average.

The values of currents flowing in the structure are determined by the indirect method, which is not very precise, especially in poorly insulated underground constructions. All treatments and corrections introduced to the measuring system by the technical method when determining the longitudinal resistance of the section relate to the resistance at a given moment of measurement. Using this value in a different period of time means assuming the stability of the determined longitudinal resistance in time. This assumption may raise objections, especially if after measurements on a given section works related to sealing the structure with the use of injections were carried out. In addition, the voltage drops on the structure are measured in millivolts and therefore the shift of the zero value of the transducers should be checked. Despite these reservations, changes in the currents in the structure, i.e. voltage drops on the structure resulting from the hours of night silence and the peak of traction vehicle traffic are clearly visible. The introduction of changes in the combination of passive protection against stray currents also causes visible changes especially on average values in the flows of currents in the structure both in the night hours and in the peaks in vehicle traffic. The values of currents flowing through individual fragments of the structure and their changes can be an indicator, but in the hours of quiet night-time, the average 30 minutes are not equal to zero. This indicates the currents of the macroelegia or depolarization of the structure if the average decreases during the night silence and makes it difficult to assess the threat.

The most important criterion for assessing the corrosion hazard of an underground structure from stray currents is to change the potential of this structure. According to the standard [16], which is the equivalent of the European standard, it can be assumed that the risk of subway construction by electrolytic corrosion does not "occur". Then the corrosion rate of the structure is technically acceptable if the average value of the potential shift relative to the ground $\triangle \mathrm{TC}$ in the hour of peak traffic, in relation to the value of this potential in the absence of stray currents, it is smaller than

$$
\Delta \mathrm{TC}=\mathrm{TCsz}-\mathrm{TCn}<+100 \mathrm{mV},
$$

where TCsz is the average value of the potential of the tunnel during the morning rush $(6: 30$ am - 8:30 pm) or the afternoon peak (hours 14: 30-17: 00), while TCn is the average value of this potential during the night break in traffic (between 1:00 and 3:00).

On the central section of the second metro line in Warsaw, positive shifts in the average construction potential $\Delta \mathrm{TC}$ do not exceed $+25 \mathrm{mV}$ and appear at both ends of this section. The biggest negative offset $\Delta \mathrm{TC}$ occurs on the body of the $\mathrm{C} 14$ station and means influencing the construction of currents flowing from nearby downtown and long-distance railway tracks. This value exceeds $-50 \mathrm{mV}$ and due to the lack of dilatation with insulation in the walls at the intersection of the chambers of this station, we have no technical possibility to investigate the impact of changing the longitudinal resistance of the station body to reduce the amplitude of changes $\Delta \mathrm{TC}$. 
Currently, comparative work is being carried out on the correlations of recorded quantities and the risk of construction and signalling of short-circuits in the return network in relation to the construction of tunnels.

\section{Short circuit detection}

Since the short circuit condition of the subway's underground network with its construction is extremely undesirable from the point of view of durability of the underground substructure, the SCM system has been equipped with a procedure for detecting short-circuit conditions. On the second line, a pair of ST and TC signals are used for this purpose. During peak hours, for each 30 minutes, average values of positive and negative ST values are calculated and for extreme values selected for the selected TC values. If the signal pair meets the following two conditions simultaneously:

for the negative average UST30- $>$ USTg- oraz TCmin $<$ TCgrmin

for the positive average UST30 $+<$ USTg + oraz TCmax $>$ TCgrmax

then this system signals the short circuit providing values that have exceeded the limit values. These values were determined as a result of long-term observation of the normal condition of subway rides with passengers both on working days and holidays as well as calculations of ST average values for individual 30 minute time intervals in the morning and afternoon peaks hours. From over 5 months of observation, positive and negative mean values were calculated for each ST. The scatter of results of individual 30-minute averages was checked. The value of USTg- and USTg + for a given measurement point was assumed 35\% of the relevant calculated long-term averages. A similar analysis related to the multiplicity of $\mathrm{TC}$, which are much more numerous in the system, but some of the mounted electrodes generate signals with unexpected waveforms, for example, the lack of characteristic diurnal changes in the potential of the structure. In the case of potentials, the extreme values were recorded during normal operation. The shorter amplitude electrodes were selected for signalling short circuits. The final verification of the accepted limit values was a 30-minute controlled short-circuit at the terminals of the device used for passenger paralysis.

Unfortunately, before attempting to look for a fault location, the results of the registration from the fault signalling period should be reviewed. An important hint is the direction of currents in the structure. At the short-circuit, the currents flow or flow at the same time depending on the ST voltage polarization. The section of measurement of voltage drop on the structure where the short-circuit occurs shows undefined momentary values or the average ones and the neighbouring ones have opposite signs. A serious obstacle in this analysis may be exceeding the measuring ranges of the voltage drop transducers on the structure. One should then look for short time intervals when there are no exceedances of the transducer range. When selecting the area to look for a fault location, it is also worth comparing the time courses of potentials near the minimum ST values. Fluctuations in the potential of the electrodes on the side of the short circuit in tracks and walls tend to be higher there. The potential variation due to the short circuit of the subway return network with the structure would most probably be greater if the reference electrodes were installed up to $3 \mathrm{~m}$ above the subway bus head, and not as in the case of the central section up to $4 \mathrm{~m}$ below the ground surface. The service life will show where the damage of the return network to the structure will occur. In the initial period of the start-up there were damage to the insulation on the crossover and the placement of the equipment connected to the return network, and mounted on the traction substation of the C11 station. The lack of secretion of track sections on the second metro line during the night hours is a significant barrier to locating and searching for the location of a short circuit in the area. 


\section{Protection against electric shock}

Tips on how to ensure electrical safety in traction systems are given in the standard [14]. The maintenance of spacing and insulating covers, etc., is implemented in the design of the subway traction system installation design taking into account the requirements [14]. Good insulation of the rails, on which metro depots move, favours, according to [5], an increase in voltage between the rails and reinforcement of the structure, i.e. an earthing bus with the same load of the power system. The ST voltage is also dependent on the distance between the supply substations of the trains. The recommended distance between traction substations is no more than $2 \mathrm{~km}$ and is usually provided on the central section of the underground. With a classic two-sided power supply using four built-in traction substations, the supply area includes sections of two lines between neighbouring substations. While maintaining the safety conditions of vehicle traffic control, the replacement of the subway train's braking energy with such a power supply solution occurs only when there is a train running in the opposite direction on the adjacent track between these substations in the supply area. This phenomenon occurs only with dense train traffic and is still rather accidental. In order to increase the efficiency of energy recuperation for the neighbouring vehicle to the grid during the braking of each of the lines on the composition line, an extended area of two-sided power supply was introduced to the entire section of the underground line II accessible to passengers. Four substations work on the common area, two of which work like two-sided power supply, while two internal ones support power while working in parallel. The side-effect of this solution is the increase in the bus bar voltage ST, while maintaining the density of passenger trains. The beneficial effect of increasing the supply area is to reduce the peak of current consumption from individual substations as well as the amount of energy received from the power supply grid [1]. The design solution of the traction power system on the central section of the underground enables the switching of the power supply system. In Fig. 4, the tunnel voltage distribution on the central section of the second metro line is shown for comparison, divided into two supply areas. This division is made on the C13 traction position. The time interval includes a fragment of the morning hours of the morning and concerns November 23, 2015, the same day as in Figures 2 and 3. As a result of dividing power supply areas, both the extreme and average values are reduced.

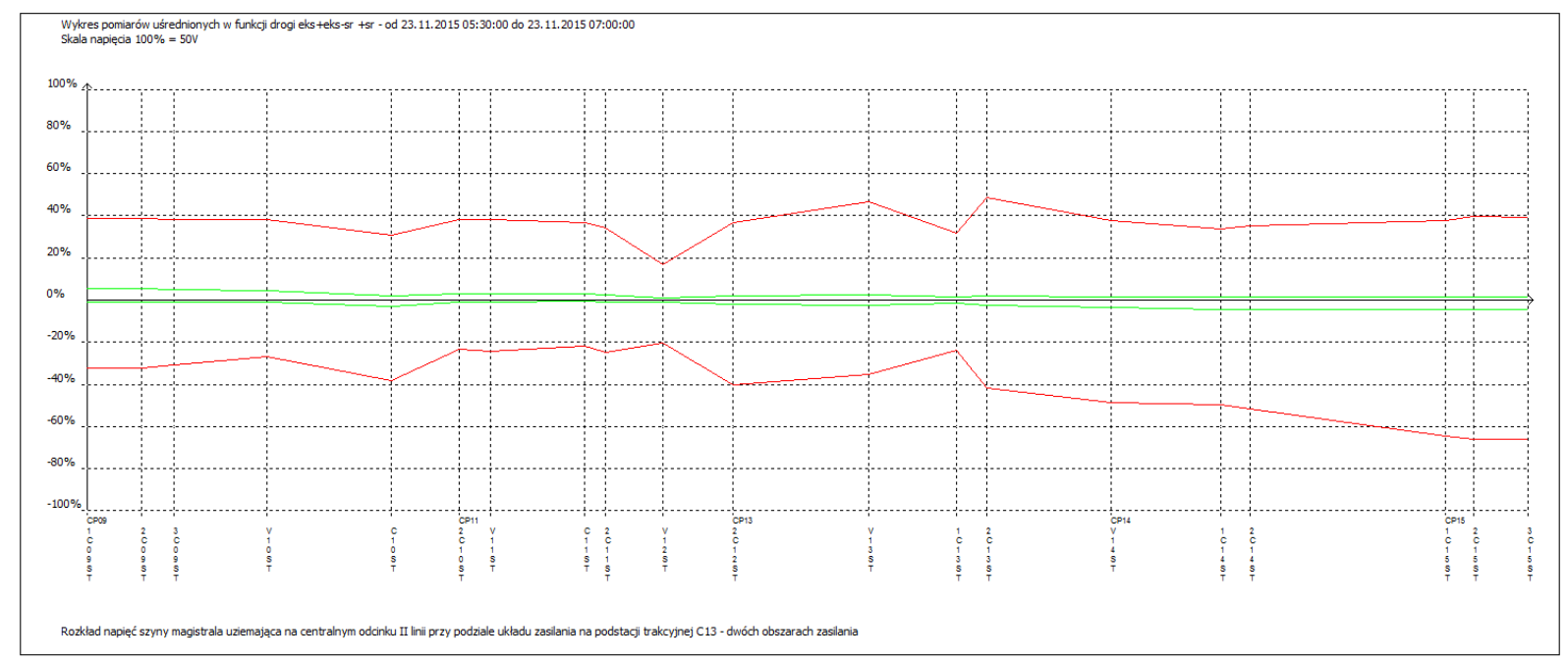

4. An example diagram of rail voltage distribution along the central section of the second metro line registered on November 23, 2015, between 5:30 and 7:00. The graph was formed from averaged values. The red colour indicates the extreme values occurring in the analysed time interval; green colour means positive and negative mean values for the same time interval. 
In Fig. 5, the tunnel bus voltage distribution is visible on the central section of the second metro line with one supply area the same as in Fig. 2 and 3. The results show the short-circuit condition of the return network with the structure that took place on the C11 traction substation. For comparison with Figures 2-4, the same voltage scale and the morning peak time range of 6:30 - 8:00 were assumed on the graph.

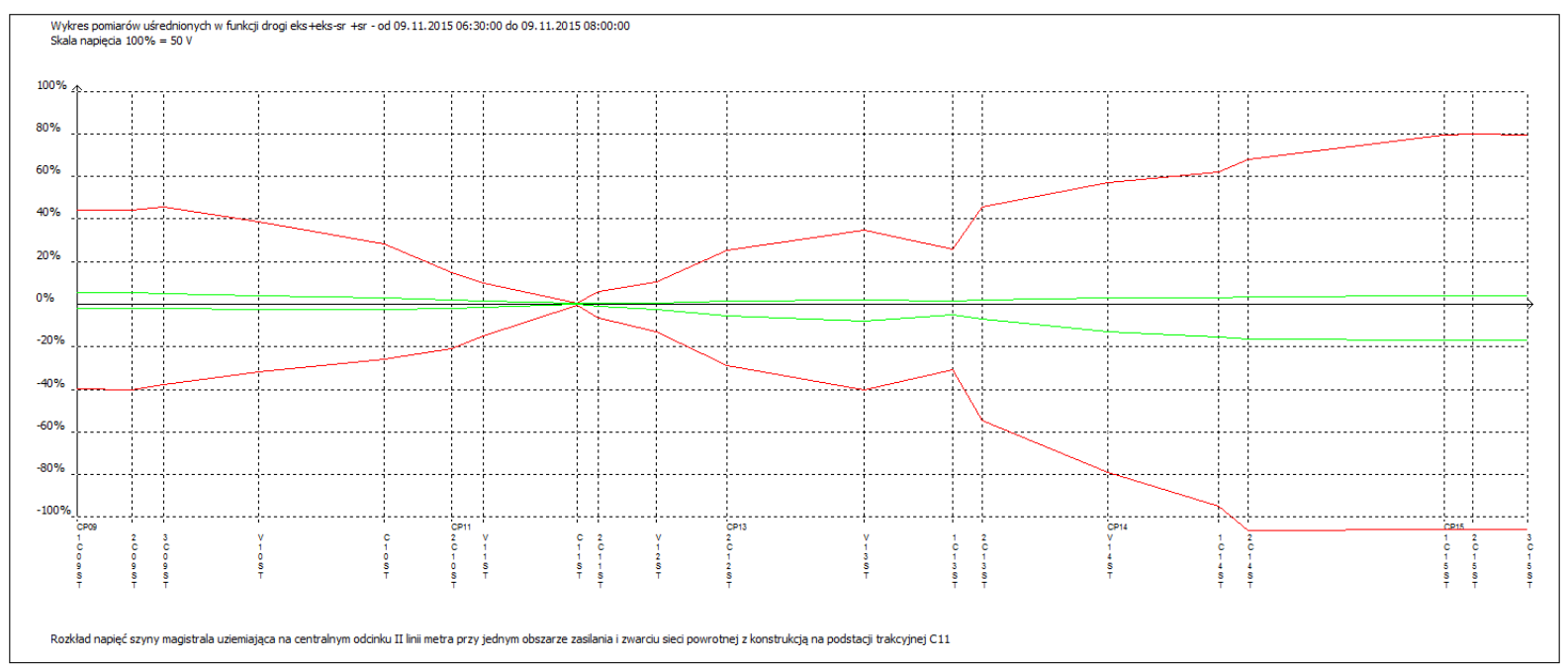

5. An example graph of rail voltage distribution along the central section of the second metro line registered during the short circuit of the return network with the structure on C11 on 09.11.2015 between 6:30 and 8:00. The graph was formed from averaged values. The red colour indicates the extreme values occurring in the analysed time interval; green colour means positive and negative mean values for the same time interval.

Adoption of the time interval covering the morning peak on the same day of the week allows for the assumption that train traffic was carried out in accordance with the timetable and the traffic of trains was similar. Thus, the conditions on the load side of the overhead contact line are similar and empower to compare, inter alia, ST voltages. When comparing both maximum and average values, it is clearly visible that the voltage on the final part of the Prague section of the II line of the underground will be increased at C11. In the vicinity of the fault location, the ST values tend to zero. Similar phenomena are observed on the first metro line $[6,3]$.

If the extension of the central section of the second metro line will be accompanied by rail short-circuits on the sections under construction with metal-connected rails of the consumed and built parts, then it should be expected that ST voltage increases on the section operated on the opposite side of the circuit location. Currently, the maximum ST voltage values do not exceed $60 \mathrm{~V}$ and are safe voltage values from the point of view of the standard [14]. In the light of experience in the construction and operation of the first metro line [6], it is expected to even double the ST voltage in the case of short-circuits on the developed second line in the second stage. After starting the parts built in the second stage of the ST voltage with maximum values twice as large as at present, it is highly probable that the density of metro trains will be maintained over a longer distance. Thus, the voltage values between the line structure II and the I rails (V11STI and C11STI) shown in Table 1 will not differ as much as at present. An accidental short-circuit on the extended central section of the second line at one end will cause ST voltage with the values referred to in [14] as dangerous. To ensure safety, especially passengers embarking or disembarking from trains, on the second line, systems with an element [11] limiting the voltage were applied by installing these systems on 
traction substations, and in the case of even stations (C10 and $\mathrm{C} 12)$ in switchgears at passenger platforms level. The installation of this system on the metro substation resembles the solution of Electronic Earth-fault Protection on railway and tramway substations. The voltage characteristics of the varistor elements [11] declared in the manufacturer's documentation correspond to the voltage requirements of the standard [14], with one small note they do not keep the time delays given for individual voltage values given in [14]. The use of such a solution for low voltage ST meets all safety requirements. The predicted increase in ST voltages, in particular durations of maximum values resulting from the traction currents of moving metro trains, suggests that the applied protection acting too quickly will contribute to the occurrence of short-circuits and thus for the digestion and electrochemical corrosion of the subway underground structure. A very unfavourable phenomenon of mutual stimulation of safeguards located at opposite ends of the operated metro section cannot be ruled out. Organization of information on the work status of each device on the second line will make it impossible to recognize the above phenomenon. The dynamics of the response of the protection system in traction overhead substations, e.g. EZZ, and immediate operation also causes "side" corrosive effects on the substation earths. In the cases of these solutions, the repair related to the rebuilding of the earth electrode is much simpler than the reconstruction of the underground subway construction.

\section{References}

[1] Ber P., Dąbrowski J., Magdalińska A.: Skutki wprowadzenia efektywniejszego układu zasilania $z$ punktu widzenia rekuperacji energii na sieć powrotna metra warszawskiego XII Ogólnopolska Konferencja Naukowa Trakcji Elektrycznej i IV Szkoła Kompatybilności Elektromagnetycznej w Transporcie SEMTRAK'2006, Zakopane październik 2006 s. 9-16.

[2] Dąbrowski J., Dziuba Wł.: Wpływ kabli RPZ „Pałac” na prady bładzace warszawskiego metra X Jubileuszowa Ogólnopolska Konferencja Naukowa Trakcji Elektrycznej SEMTRAK'2002, Zakopane październik 2002 s. 427-436.

[3] Dąbrowski J., Dziuba Wł.: Wykrywanie przypadkowych zwarć pomiędzy szynami a tunelem w metrze warszawskim MET 2001 Gdańsk 31.05 - 2.06.2001r.

[4] Dąbrowski J.: Drobne, lecz istotne problemy wynikajace z izolowania podziemnej konstrukcji metra Wiadomości Elektrotechniczne 2011, 7, 33-41.

[5] Dąbrowski J.: Kompromisy pomiędzy wymaganiami bezpieczeństwa elektrycznego a wymaganiami ograniczania upływu prąów błązacych z trakcji elektrycznej na przykładzie warszawskiego metra SPES'98 I Międzynarodowa Konferencja Naukowo-Techniczna Bezpieczne Urządzenia Energoelektroniczne 24-27.11.1998 Warszawa-Międzylesie s. 237-242.

[6] Dąbrowski J.: Rozkład napięcia szyny - tunel w metrze warszawskim MET 2007 Warszawa 27-29.09.2007r.

[7] Dziuba W., Dąbrowski J.: Orientacyjna ocena stanu tramwajowej sieci powrotnej jako źródta prądów błądzących OpK 1999r nr 8 s. 202 - 205 (Ochrona przed Korozją).

[8] Dziuba Wł., Dąbrowski J.: Rezystancje w obwodach prądów powrotnych warszawskiego metra VII Konferencja Naukowa Trakcji Elektrycznej SEMTRAK'96, Zakopane październik 1996 s. 213-220.

[9] IMR 4 Instrukcja obsługi 2010 KOLEN.

[10] IMU 110 Instrukcja obsługi 2007 Sonel.

[11] Low-Voltage Limiter HVL 120-0.3 Dokument ID 1HC0075863 E01 AB.

[12] Matus H.: Oddziaływanie prąów tellurycznych na rurociagi chronione katodowo XII Krajowa Konferencja Pomiary Korozyjne w Ochronie Elektrochemicznej Jurata 
19-21.09.2012 s. 131-142.

[13] PN-92/E-05024 Ochrona przed korozją. Ograniczenie upływu prąów z trakcyjnych sieci powrotnych pradu statego.

[14] PN-EN 50122-1 - Zastosowanie kolejowe. Urzadzenia stacjonarne. Czesść 1: Środki ochrony dotyczace bezpieczeństwa elektrycznego i uziemień.

[15] PN-EN 50122-2 - Zastosowanie kolejowe. Urzadzenia stacjonarne. Czesść 2: Środki ochrony przed oddziaływaniem prąów błądzacych wywołanych przez trakcje elektryczna pradu statego.

[16] PN-EN 50162 Ochrona przed korozja powodowana przez prądy błądzace układów prądu statego.

[17] Sokołowski M.: Metro Warszawskie - innowacyjność, bezpieczeństwo, strategie utrzymania infrastruktury IX Konferencja Naukowo-Techniczna Projektowanie, Budowa i utrzymanie Infrastruktury w Transporcie Szynowym INFRASZYN 2016 s. $61-79$. 